\title{
Ice sheet record of recent sea-ice behavior and polynya variability in the Amundsen Sea, West Antarctica
}

\author{
Alison S. Criscitiello, ${ }^{1,2}$ Sarah B. Das, ${ }^{2}$ Matthew J. Evans, ${ }^{3}$ Karen E. Frey, ${ }^{4}$ \\ Howard Conway, ${ }^{5}$ Ian Joughin, ${ }^{5,6}$ Brooke Medley, ${ }^{5}$ and Eric J. Steig ${ }^{5,7}$ \\ Received 22 March 2012; revised 26 October 2012; accepted 3 November 2012; published 25 January 2013.
}

[1] Our understanding of past sea-ice variability is limited by the short length of satellite and instrumental records. Proxy records can extend these observations but require further development and validation. We compare methanesulfonic acid (MSA) and chloride $\left(\mathrm{Cl}^{-}\right)$ concentrations from a new firn core from coastal West Antarctica with satellite-derived observations of regional sea-ice concentration (SIC) in the Amundsen Sea (AS) to evaluate spatial and temporal correlations from 2002-2010. The high accumulation rate $\left(\sim 39 \mathrm{~g} \cdot \mathrm{cm}^{-2} \cdot \mathrm{yr}^{-1}\right)$ provides monthly resolved records of MSA and $\mathrm{Cl}^{-}$, allowing detailed investigation of how regional SIC is recorded in the ice-sheet stratigraphy. Over the period 2002-2010 we find that the ice-sheet chemistry is significantly correlated with SIC variability within the AS and Pine Island Bay polynyas. Based on this result, we evaluate the use of icecore chemistry as a proxy for interannual polynya variability in this region, one of the largest and most persistent polynya areas in Antarctica. MSA concentrations correlate strongly with summer SIC within the polynya regions, consistent with MSA at this site being derived from marine biological productivity during the spring and summer. $\mathrm{Cl}^{-}$concentrations correlate strongly with winter SIC within the polynyas as well as some regions outside the polynyas, consistent with $\mathrm{Cl}^{-}$at this site originating primarily from winter sea-ice formation. Spatial correlations were generally insignificant outside of the polynya areas, with some notable exceptions. Ice-core glaciochemical records from this dynamic region thus may provide a proxy for reconstructing AS and Pine Island Bay polynya variability prior to the satellite era.

Citation: Criscitiello, A. S., S. B. Das, M. J. Evans, K. E. Frey, H. Conway, I. Joughin, B. Medley, and E. J. Steig (2013), Ice sheet record of recent sea-ice behavior and polynya variability in the Amundsen Sea, West Antarctica, J. Geophys. Res. Oceans, 118, 118-130, doi:10.1029/2012JC008077.

\section{Introduction}

[2] The Amundsen Sea (AS) has experienced a significant decline in sea-ice extent (SIE) over the last quarter century [Comiso and Nishio, 2008; Turner et al., 2009], in contrast

All Supporting Information may be found in the online version of this article.

${ }^{1}$ MIT/WHOI Joint Program in Oceanography/Applied Ocean Sciences and Engineering, Woods Hole Oceanographic Institution, Woods Hole, Massachusetts, USA.

${ }^{2}$ Department of Geology and Geophysics, Woods Hole Oceanographic Institution, Woods Hole, Massachusetts, USA.

${ }^{3}$ Department of Chemistry, Wheaton College, Norton, Massachusetts.

${ }^{4}$ Graduate School of Geography, Clark University, Worcester, Massachusetts, USA.

${ }^{5}$ Department of Earth and Space Sciences, University of Washington, Seattle, Washington, USA.

${ }^{6}$ Applied Physics Laboratory, University of Washington, Seattle, Washington, USA.

${ }^{7}$ Quaternary Research Center, University of Washington, Seattle, Washington, USA.

Corresponding author: A. S. Criscitiello, Department of Geology and Geophysics, Woods Hole Oceanographic Institution, Woods Hole, MA 02543, USA. (acriscitiello@whoi.edu)

(C2012. American Geophysical Union. All Rights Reserved. 2169-9275/13/2012JC008077 to increasing SIE trends around the rest of Antarctica and coincident with regional ice-sheet surface warming [Steig et al., 2009; Schneider et al., 2011]. The West Antarctic Ice Sheet (WAIS) is susceptible to both marine intrusions of warm, moist air [Nicolas and Bromwich, 2011] and changes in ocean heat transport beneath its ice shelves [Jenkins et al., 2010; Jacobs et al., 2011; Steig et al., 2012]. This has resulted in the highest rates of mass loss and glacier acceleration in Antarctica outside of the Antarctic Peninsula. Widespread mass losses along the Amundsen-Bellingshausen Sea have increased the ice-sheet loss by nearly $60 \%$ between 1996 and 2006 alone [Rignot et al., 2008]. The most significant rates of mass loss and acceleration have occurred in the Pine Island and Thwaites Glacier regions of WAIS (Figure 1) [Rignot et al., 2008].

[3] Antarctic coastal polynyas can affect regional oceanatmosphere heat exchange and play an important role in winter sea-ice production, upwelling, deep-water formation, and biological productivity. In West Antarctica, polynya variability may be particularly important in the context of recent sea-ice decline in the AS and mass loss of the adjacent WAIS [e.g., Rignot et al., 2008]. Polynya variability within the AS and Pine Island Bay (PIB) polynyas may contribute to these observed ice-sheet changes, most notably by influencing 


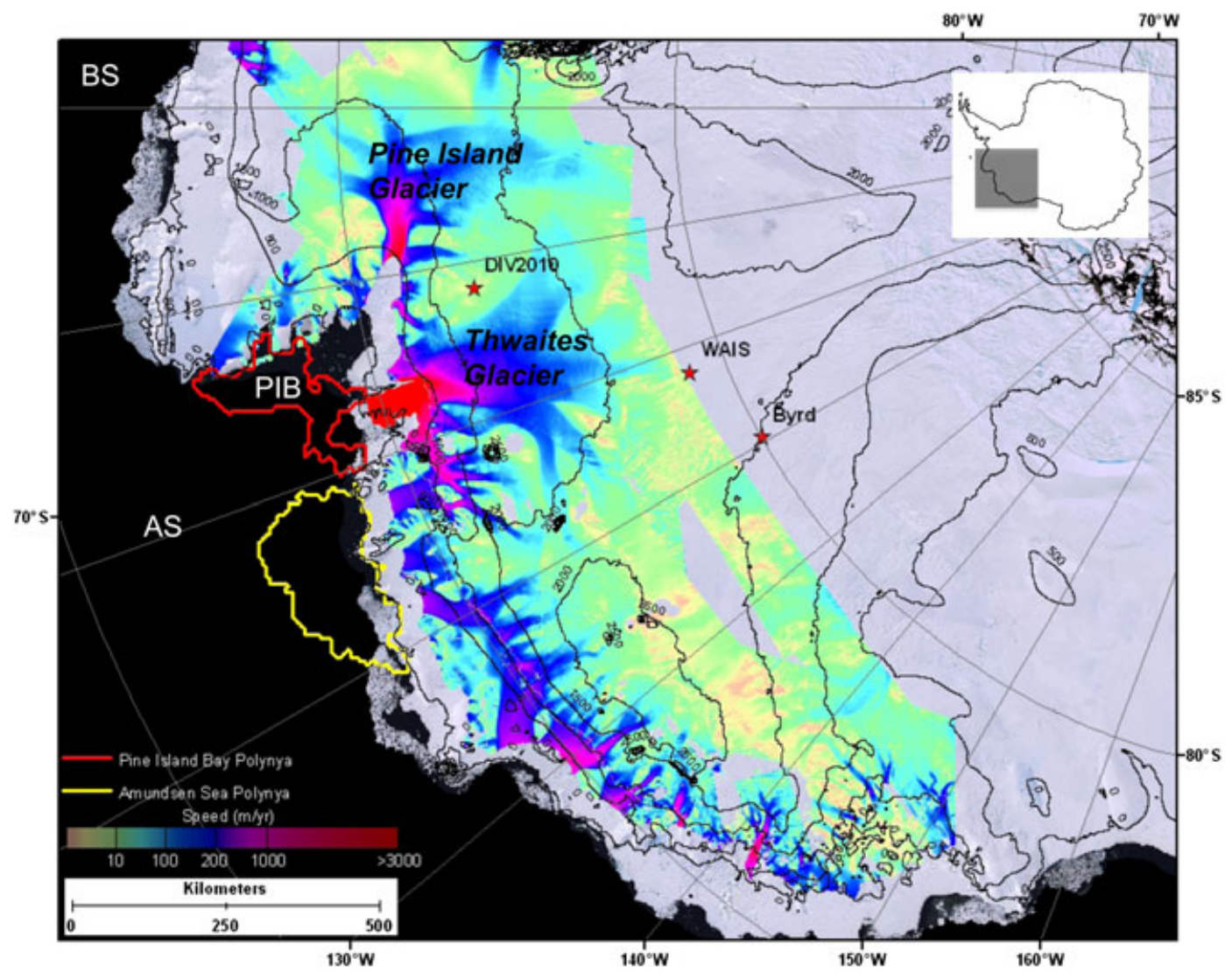

Figure 1. Regional setting of coastal West Antarctica. Grey box in inset shows map location. Glacier speeds $\left(\mathrm{m}^{\cdot} \mathrm{yr}^{-1}\right)$ derived from InSAR data [I. Joughin]. Background MODIS mosaic of Antarctica is shown with $500 \mathrm{~m}$ contour intervals. The DIV2010 drill site on the divide between Thwaites and Pine Island Glaciers is at an elevation of $1292 \mathrm{~m}$. Byrd and WAIS Divide are also shown. PIB = Pine Island Bay, AS = Amundsen Sea, BS = Bellingshausen Sea. The PIB polynya mask is shown in red, and the AS polynya mask is shown in yellow. This region has experienced rapid change since 1979 which has been attributed to increased subglacial melting, warming surface temperatures, and susceptibility to intrusions of warm, moist marine air [e.g., Zwally et al., 2002].

coastal sea-ice production, ocean circulation, ice-shelf melting and retreat, and ice-sheet dynamics. Polynyas are often considered to be wintertime phenomena since they are, by definition, areas of open water or reduced sea-ice cover located in a region where surrounding waters are icecovered. In spring, surface waters associated with polynyas are often biologically productive because they are the first polar marine systems to be exposed to springtime solar radiation, either because they are ice free or their thin seaice cover is more susceptible to early breakup in the spring [Mundy and Barber, 2001]. While technically no longer polynyas, these non-winter features are biogeochemically and thermodynamically important. Owing to their close relationship to winter polynyas, these areas in spring and summer will be referred to here as post-polynyas following others [e.g., Arrigo and van Dijken, 2003].

[4] Winter sea-ice production, local biology, and regional ocean-atmosphere heat exchange can be strongly impacted by the presence of polynyas, even though they make up only a small fraction of the coastal Southern Ocean [Maykut, 1982]. Surface waters associated with coastal polynyas are regions of enhanced primary and secondary production [Grebmeier and Cooper, 1995; Mundy and Barber, 2001; Arrigo and van Dijken, 2003]. Growth and accumulation of phytoplankton biomass are much greater within polynyas than in adjacent waters, with rates of primary production often exceeding $1 \mathrm{~g} \cdot \mathrm{C} \cdot \mathrm{m}^{-2} \cdot \mathrm{d}^{-1}$ [Arrigo et al., 2000] and the proportion of new to regenerated production generally high [Smith et al., 1990]. Polynya dynamics for some Antarctic polynyas have been quantified over the satellite era [e.g., Massom et al., 1998; Fichefet and Goosse, 1999; Bindoff et al., 2001; Arrigo and van Dijken, 2003], increasing our understanding of their spatial and temporal variability. Obtaining longer-term, pre-satellite-era records of both sea-ice and polynya variability is critical to our understanding of the climate system, ocean circulation, and biological productivity across the Antarctic.

[5] Previous efforts have attempted to develop sea-ice proxies using ice- and firn-core records. Sea salt sodium $\left(\mathrm{ssNa}^{+}\right)$ and other sea-salt aerosol ions $\left(\mathrm{Cl}^{-}, \mathrm{Mg}^{+}, \mathrm{K}^{+}, \mathrm{Ca}^{2+}, \mathrm{SO}_{4}{ }^{2-}\right)$ have been used as qualitative proxies for regional SIE around Antarctica. Some studies have proposed that sea-ice formation processes, including frost flower formation and brine production, as well as blowing snow released from sea-ice surfaces, are the dominant source of sea-salt aerosol transport to Antarctic glacial ice [Rankin et al., 2002; Wolff et al., 2003; 
Kaleschke et al., 2004; Wolff et al., 2006; Fischer et al., 2007; Yang et al., 2008; Roscoe et al., 2011]. Other studies, however, have instead suggested that open water in the marginal sea-ice zone, particularly during stormy seasons, promotes increased production, transport, and deposition of sea-salt aerosols [Petit et al., 1999; Kinnard et al., 2006; Abram et al., 2011]. Observations of enhanced sea-salt aerosol fluxes are difficult to interpret with respect to their ultimate drivers, as enhanced fluxes can reflect increased open water in some cases, or increased sea-ice cover in other cases.

[6] The use of methanesulfonic acid (MSA) concentrations in Antarctic ice and firn cores has also been explored as a potential sea-ice proxy. During and after sea-ice breakup, phytoplankton blooms release dimethylsulfoniopropionate (DMSP) which degrades to dimethyl sulfide (DMS) by several biologically-mediated processes (e.g., phytoplankton cell lysis or grazing by zooplankton) [Dacey and Wakeham, 1986]. It has been shown that in low-nutrient, subtropical, oligotrophic regions, DMS production results from physiological stress such as UV radiation [Toole and Siegel, 2004], whereas DMS production in polar regions is bloomforced and therefore directly linked to phytoplankton activity [Curran and Jones, 2000]. In the Southern Ocean, DMS-producing phytoplankton are dominated by sea-ice algae [Curran et al., 2003]. Changes in brine volume associated with increased permeability of sea-ice cover as it warms and thins have been shown to directly affect DMS and DMSP migration through the brine network in Antarctic sea ice, significantly contributing to the atmospheric sulfur budget [Tison et al., 2010]. DMS is oxidized in the atmosphere to MSA [Ravishankara et al., 1997], which is then deposited by solid precipitation onto the adjacent ice sheet [Saigne and Legrand, 1987; Gibson et al., 1990]. While oxidation of MSA is greatly reduced during polar darkness, the process has still been shown to occur year-round, depending primarily on the $\mathrm{BrO}$ oxidation pathway [Jourdain and Legrand, 2001; Breider et al., 2010].

[7] The timing, duration, and spatial extent of sea-ice breakup should therefore exert a control on the timing and amount of both DMSP produced and MSA precipitated on the ice sheet. There is no other known source of MSA [Mulvaney et al., 1992]. Previous studies have shown there are both strong negative correlations [Pasteur et al., 1995; Isaksson et al., 2005; Abram et al., 2007; Rhodes et al., 2009; Abram et al., 2011] and strong positive correlations [Welch et al., 1993; Legrand et al., 1997; Curran et al., 2003; Abram et al., 2010] between time series of MSA concentrations and SIE, suggesting that MSA concentrations are influenced by many factors including local sea-surface and air temperatures, precipitation, winds, and general seaice conditions [Hezel et al., 2011]. Precipitation and winds in particular may confound the interpretation of MSA records, as high MSA production does not necessarily mean high MSA concentrations reaching the ice sheet if precipitation is low or winds are offshore. These regional studies vary in local meteorology, climate, elevation, and distance from the coast. Additionally, previous studies have not always clearly defined whether their proxies indicate annual mean or maximum sea ice, nor whether their proxies are indicative of sea-ice concentration (SIC) or extent. The recent use of sea-salt and MSA records from the International Trans-
Antarctic Scientific Expedition (ITASE) cores collected across WAIS revealed that maximum and mean annual concentrations for both species correlated significantly with maximum, mean, and minimum annual SIE in the Amundsen-Bellingshausen Sea $\left(230^{\circ}-290^{\circ}\right)$ [Sneed et al., 2011], and highlighted the effectiveness of combining MSA and sea-salt records when investigating the marine influence on ice-sheet chemistry.

[8] Our understanding of modern climate and past change in the AS and PIB requires attaining reliable records of seaice behavior and biological production prior to the satellite era. While aforementioned studies have used sea-salt aerosols and/or MSA to investigate sea-ice extent, here we examine how such glaciochemical records may provide additional insight into polynya behavior. In this study, we present new high temporal resolution (monthly) records of MSA and $\mathrm{Cl}^{-}$from the divide between Thwaites and Pine Island Glaciers (Figure 1) over the past decade (2001-2010), and investigate the use of MSA and $\mathrm{Cl}^{-}$records as proxies for variability within the Amundsen Sea, specifically within the AS and PIB polynya regions. In this study we explicitly explore the relationships between several sea-ice and ice-sheet variables in a more rigorous way than has been done in previous studies. This work allows for reconstructions of SIC and polynya activity using measurements of ice cores extending beyond the satellite era, bridging a critical gap in our understanding of past climate and sea-surface conditions.

\section{Methods}

\subsection{Site Description}

[9] The DIV2010 core site $\left(76.768^{\circ} \mathrm{S}, 101.735^{\circ} \mathrm{W}\right)$ is located on the drainage divide between Thwaites and Pine Island glaciers (Figure 1). This site is $1292 \mathrm{~m}$ above sea level and $180 \mathrm{~km}$ from the coast of PIB. The ice speed at this location is $\sim 10-20 \mathrm{~m}^{\prime} \mathrm{yr}^{-1}$ [Joughin et al., 2003]. The DIV2010 firn core used in this study was collected in December 2010 using a 3 inch diameter Pico hand auger and is $7.94 \mathrm{~m}$ long, with a corresponding bottom age of October 2001. Age-depth relationship and accumulation rates were established by matching the $\delta^{18} \mathrm{O}$ firn-core record (Figure 2) with regional surface temperature data. Using this method we calculated a mean accumulation rate of $\sim 39 \mathrm{~g} \cdot \mathrm{cm}^{-2} \cdot \mathrm{yr}^{-1}\left(\sigma=8.7 \mathrm{~g} \cdot \mathrm{cm}^{-2} \cdot \mathrm{yr}^{-1}\right)$ and determined that annual accumulation is relatively equally distributed seasonally. The high accumulation rates allow for sub-seasonal resolution of the DIV2010 core records, as well as limit post-depositional loss of MSA [Weller et al., 2004]. Further detail on core handling, core physical properties, and core dating is included in the Supporting Information.

\subsection{Lab Methods and Glaciochemical Time Series}

[10] The outer $2 \mathrm{~cm}$ of each core was removed, and the core was then subsampled into $3-5 \mathrm{~cm}$ thick slices ( $\sim 14$ samples/yr) depending on the location of core breaks. These slices were cut in half longitudinally, one sample used for analysis of oxygen isotopes, the other sample used for MSA and $\mathrm{Cl}^{-}$analyses. Samples were kept frozen until the day of analysis. $\delta^{18} \mathrm{O}$ analyses were run on a Picarro cavity ring-down spectroscopy analyzer (precision for $\delta^{18} \mathrm{O}$ of water samples is $\leq 0.1 \%$ ). The $\delta^{18} \mathrm{O}$ time series was used to derive an age-depth scale for the geochemical records, further described in the Supporting Information. 


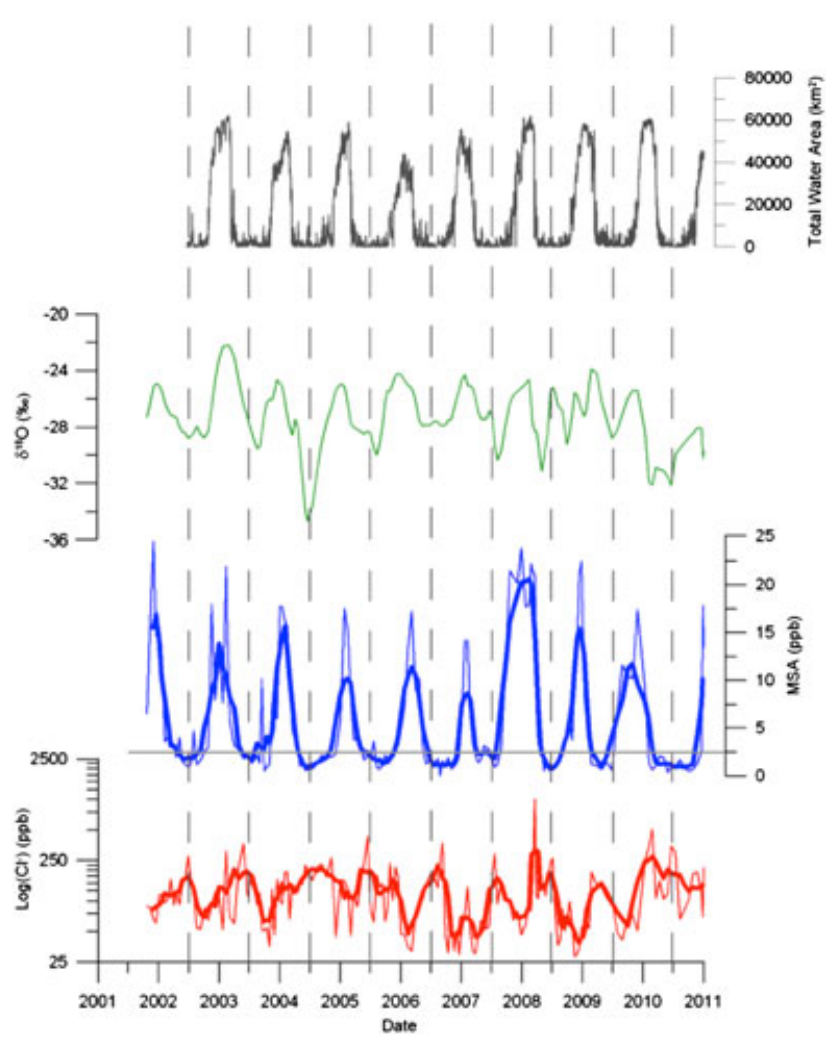

Figure 2. Chemical time series in the DIV2010 core and total open water area within AS and PIB polynyas. Total polynya open water area (grey), $\delta^{18} \mathrm{O}$ (green), MSA (blue), and $\mathrm{Cl}^{-}$(red; shown as $\left.\log \left(\mathrm{Cl}^{-}\right)\right)$are shown. Thick red and blue lines are a 5-point running mean. Vertical black dashed lines indicate mid-winter (June 1) of each year, and the horizontal grey line indicates the MSA detection limit (the entire $\mathrm{Cl}^{-}$time series lies above the $\mathrm{Cl}^{-}$detection limit of $0.8 \mathrm{ppb}$ ). $X$-axis years indicate the start (January) of a year.

[11] MSA and $\mathrm{Cl}^{-}$analyses were performed simultaneously on a Dionex ICS1000 Ion Chromatograph (IC) using suppressed ion chromatography after Curran and Palmer [2001]. The IC is equipped with small-bore tubing and columns $(2 \mathrm{~mm})$ and a $240 \mu \mathrm{L}$ sample loop to increase sensitivity. MSA analyses were performed using Dionex AG/AS 14 columns and a $2 \mu \mathrm{M}$ sodium-borate eluent [Curran and Palmer, 2001; Morganti et al., 2007]. Standards were prepared daily and blanks were evaluated before and after each sample. A daily 5-point calibration curve was calculated to determine concentrations. Analytical precision is $2.8 \%$ (MSA) and $5.5 \%\left(\mathrm{Cl}^{-}\right)$, with detection limits of $2.5 \mathrm{ppb}$ (MSA) and $0.8 \mathrm{ppb}\left(\mathrm{Cl}^{-}\right)$.

[12] MSA and $\mathrm{Cl}^{-}$fluxes were calculated from the measured MSA and $\mathrm{Cl}^{-}$concentrations, firn-sample volumes, and firn-sample densities. Monthly MSA and $\mathrm{Cl}^{-}$data were calculated by linearly interpolating between measured concentrations, which are not evenly spaced in time (due to irregular core breaks, variations in accumulation rate, etc.), and then averaging these interpolated time series. Seasonal MSA and $\mathrm{Cl}^{-}$values were calculated by averaging the monthly time series; for the purposes of this study we define winter $=$ April to September, summer $=$ October to March .

\subsection{Satellite-Derived Sea-Ice Concentration and Polynya Masks}

[13] The regional development of sea-ice proxies requires direct validation utilizing satellite imagery. We used Advanced Microwave Scanning Radiometer - EOS (AMSR-E) spatial data of SIC from 2002 to 2010 [Spreen et al., 2008]. Based on passive microwave brightness temperatures, the daily AMSR-E product provides $6.25 \mathrm{~km} \times 6.25 \mathrm{~km}$ resolution gridded SIC, ranging from $0 \%$ to $100 \%$. While we use a standard, consistent satellite sea-ice product, we note that there may be some ambiguity in the interpretation of thin ice which can effect SIC values [Markus and Cavalieri, 2000]. Minimal data gaps were spatially or temporally linearly interpolated. Monthly SIC was calculated by averaging daily SIC (January 2003 to December 2010). Summer SIC was calculated by averaging October to March monthly SIC (October 2002 to March 2010), and winter SIC was calculated by averaging April to September monthly SIC (April 2003 to September 2010). Monthly and seasonal spatial correlation maps were then generated between monthly and seasonal AMSR-E sea-ice time series and monthly and seasonal ice-core glaciochemical time series, respectively. Monthly correlations had 96 pairwise comparisons, whereas seasonal correlations had 8 pairwise comparisons. All correlations reported are statistically significant $(p<0.1$, monthly threshold $|r|>0.169$ and seasonal threshold $|r|>0.622$, accounting for differing degrees of freedom).

[14] Previous work used daily SIC images to map the number of ice-free winter days (June to October) at each pixel location [Arrigo and van Dijken, 2003]. Such maps were in turn used to identify the location of coastal polynyas by assuming that polynyas experience the greatest number of ice-free days (using a threshold of $50 \%$ ice-free winter days to qualify as a polynya) [Arrigo and van Dijken, 2003]. Based on these masks, the AS polynya had a winter area of $3670 \mathrm{~km}^{2}$, a summer post-polynya area of $38,000 \mathrm{~km}^{2}$, a January chlorophyll- $a$ concentration of $6.98 \pm 3.32 \mathrm{mg} \cdot \mathrm{m}^{-3}$, and an annual primary production rate of $160.7 \pm 36.9 \mathrm{~g} \cdot \mathrm{C} \cdot \mathrm{m}^{-2}$ (data are based on 5 year averages, 1997-2001) [Arrigo and van Dijken, 2003]. The PIB polynya had a winter area of $1090 \mathrm{~km}^{2}$, a summer post-polynya area of $16,890 \mathrm{~km}^{2}$, a January chlorophyll- $a$ concentration of $4.36 \pm 3.28 \mathrm{mg} \cdot \mathrm{m}^{-3}$, and an annual primary production rate of $151.1 \pm 77.8 \mathrm{~g} \cdot \mathrm{C} \cdot \mathrm{m}^{-2}$ (same 5 year average as previous) [Arrigo and van Dijken, 2003].

[15] Our AS and PIB polynya masks (Figure 1, $62,344 \mathrm{~km}^{2}$ maximum total summer water area) are similar (within $7400 \mathrm{~km}^{2}$ maximum total summer water area) to the summer post-polynya areas of Arrigo and van Dijken [2003], but target the areas of significant correlation ( $r$-values of -0.4 or better $(p<0.1)$ ) between monthly SIC (across all pixels) and monthly-averaged DIV2010 MSA concentrations. These high correlations are driven largely by the strength of correlations in summer. Our chosen threshold r-value of $|r|>0.4$ is greater than the minimum for monthly statistical significance $(|r|>0.169)$ because this minimum encompasses a large part of the Amundsen Sea. An $|r|$ of 0.4 or better results in reasonable polynya regions that are comparable to Arrigo and van Dijken [2003]. These polynya masks show the characteristic spring and summer open-water (break-out) pattern for the AS region, which is particularly evident by midsummer (indicating post-polynya 
behavior). Within these polynya masks we then extracted daily open water areas by summing the pixels $(6.25 \mathrm{~km}$ $6.25 \mathrm{~km}$ ) that had $<15 \%$ SIC. We also calculate days with $<50 \%$ sea-ice cover within both polynyas. This was determined by first creating for each day a binary ice/no-ice dataset, where pixels with $>15 \%$ sea-ice cover are defined as ice, and pixels with $<15 \%$ sea-ice cover are defined as no ice. We then calculated the number of days in which $<50 \%$ of pixels in the polynya areas had sea-ice cover.

[16] Although these two polynya areas (AS and PIB) are geographically distinct, they generally open and close within a week of each other (this holds for summer and winter seasons as well). The percent of open water area within the two polynyas positively covaries $\left(r^{2}=0.8\right)$. Additionally, the ice-core record does not allow us to distinguish between these two source regions, thus we focus on combined AS +PIB polynya activity in much of the following results and discussion. When we refer to the AS and PIB post-polynyas, we refer to these same mask regions. We note that the monthly polynya SIC and monthly MSA correlations we present below will naturally be high, as this is how we have defined the polynya masks, but emphasize that the overall spatial correlation pattern shown in Figure 7 highlighting the strong correlation between monthly polynya SIC and monthly MSA is from cross-pair analyses across the entire region, and is independent of any masking.

\section{Results}

\subsection{Satellite-Derived Polynya Sea-Ice Reconstructions}

[17] AMSR-E data show strong seasonal and interannual variability in open water as well as in the timing of sea-ice breakup and formation in $\mathrm{AS}+\mathrm{PIB}$ polynya regions over the 2002-2010 period (Figure 3). Generally, sea-ice breakup within AS+PIB polynya regions begins at the end of October, with seasonal sea-ice cover minimum occurring by the end of February. The process of sea-ice formation occurs much more rapidly than breakup and typically occurs over the month of March. The rate of sea-ice breakup is generally slower than the rate of sea-ice formation. There is also more seasonal and more interannual SIC variability during breakup than during formation within AS+PIB polynya regions (over 2002-2010, mean summer total open water $\sigma=7313 \mathrm{~km}^{2}$, mean winter total open water $\sigma=823 \mathrm{~km}^{2}$, maximum interannual summer open water $\sigma=12,006 \mathrm{~km}^{2}$, and maximum interannual winter open water $\sigma=1433 \mathrm{~km}^{2}$ ).

[18] There is notable variability in interannual summer postpolynya activity during our study period. In particular, the lowest SIC within the post-polynyas (and the earliest onset of breakup) occurred during the austral summer of 2002/2003. Other years with notably low SIC within the post-polynyas are 2007/2008 and 2009/2010. The greatest summertime seaice cover occurred during the summer of $2005 / 2006$. There is also variability in the timing that peak polynya size is attained. Postpolynyas reach their maximum size as early as the beginning of January (as in 2006/2007) and as late as the beginning of March (as in 2002/2003). The AS and PIB post-polynyas closed most rapidly and steadily in 2010 (mid-March to midApril). There is also significant interannual variability in the number of days with $<50 \%$ sea-ice cover (as defined above). Year 2002/2003 had 129 days with $<50 \%$ sea-ice cover, which steadily decreased to 67 days by $2005 / 2006$. Following $2005 / 2006$, the number of days with $<50 \%$ sea-ice cover increased to 115 days by $2008 / 2009$ and remained near-constant through 2010. Annual maximum open polynya water area followed the same trend, with $61,875 \mathrm{~km}^{2}$ in $2002 / 03 \mathrm{de}-$ creasing steadily to $43,984 \mathrm{~km}^{2}$ in $2005 / 2006$, followed by an increase to $61,914 \mathrm{~km}^{2}$ in $2007 / 2008$, which remained nearconstant through 2010. While AS and PIB polynyas generally open and close within a week of each other, the percent open water within AS polynya is greater than the percent open water within PIB polynya for all summers between 2002-2010.

[19] There are also wintertime polynya events in AS and PIB polynyas, with considerable interannual variability (Figure 3). Openings have been observed in all months between April and September. Small openings $\left(6000-12,000 \mathrm{~km}^{2}\right)$ occur annually, sometimes multiple times per year, occurring most often in April, May, and September. Large openings $\left(>12,000 \mathrm{~km}^{2}\right)$ occurred in July 2002, September 2004, and April 2006. Year 2005 was notable for being the only year over the length of record without a wintertime event. The winter polynya activity is discussed below (section 4.3) in the context of the glaciochemical records.

\section{2. $\mathrm{Cl}^{-}$and MSA Concentrations}

[20] We use $\mathrm{Cl}^{-}$as the representative sea-salt species and present the log value of $\mathrm{Cl}^{-}$(owing to the non-linear character of seasonal changes in sea-salt concentration) following the recent work of others [e.g., Röthlisberger et al., 2010;

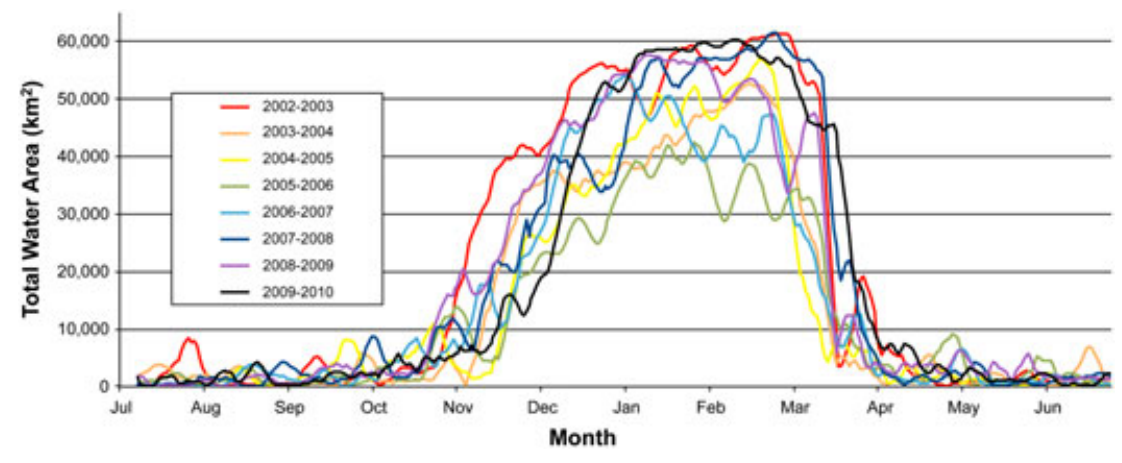

Figure 3. Total water area $\left(\mathrm{km}^{2}\right)$ within the AS and PIB polynya masks (as defined in this study, where total water area within the masks $=62,344 \mathrm{~km}^{2}$ ) combined, 2002-2010. Only 7-point running means of daily total water area are shown. 
Abram et al., 2011]. Measured $\mathrm{Cl}^{-}$concentrations at the DIV2010 core site range from 28.3-1010 ppb (Figure 2). The mean $\mathrm{Cl}^{-}$concentration over the length of the core is $128 \mathrm{ppb}$ $(\sigma=106 \mathrm{ppb})$. There is a strong seasonal signal in the $\mathrm{Cl}^{-}$concentrations (Figure 2). Annual maxima occur in winter months and annual minima occur in early to mid summer (November to December, Figure 4). We also find a smaller late summer (February to March) peak in $\mathrm{Cl}^{-}$coincident with the initiation of seaice formation that occurs during this time. The highest measured $\mathrm{Cl}^{-}$concentrations in the core occur during June 2005 (428 ppb), February 2010 (514 ppb), and March 2008 (1.01 ppm). Winter mean $\mathrm{Cl}^{-}$maxima occur earlier in 20082010 than in previous years (Figure 2).

[21] Measured MSA concentrations in the DIV2010 core range from 0 to $25 \mathrm{ppb}$ (Figure 2). The mean MSA concentration over the length of the core is $6 \mathrm{ppb}(\sigma=6 \mathrm{ppb})$. The minimum, maximum, and mean MSA concentrations are comparable to concentrations found in other recent Antarctic cores such as the James Ross Island core [Abram et al., 2011]. Annual maxima in MSA occur consistently during the austral summers (Figure 4). Austral winters correspond with annual minima in MSA concentration (Figure 4). The highest MSA concentrations occur during November 2001 (24 ppb), February 2003 (22 ppb), November/December

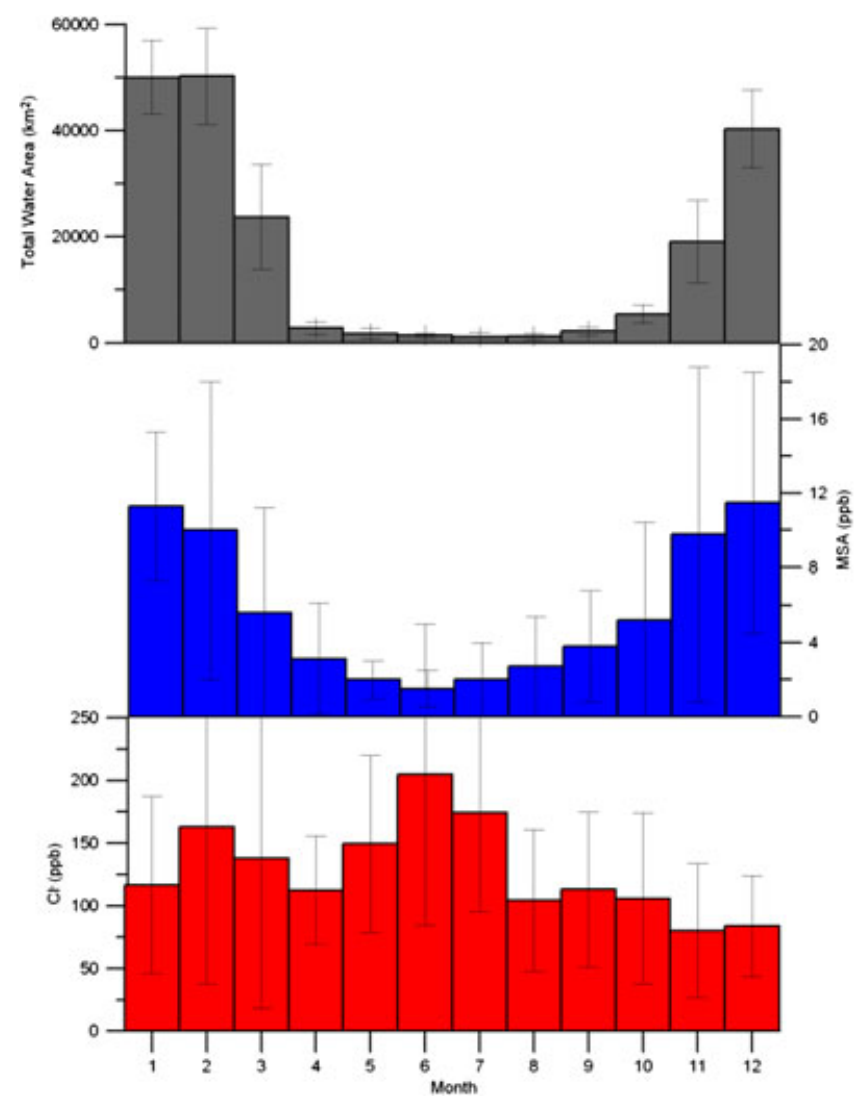

Figure 4. The composite annual cycles of $\mathrm{Cl}^{-}$(red), MSA (blue), and total polynya water area (grey) for 2002-2010. Error bars give the $1 \sigma$ range on the composite monthly means. Annual $\mathrm{Cl}^{-}$maxima occur in winter, corresponding to formation of new sea-ice surfaces within the polynyas. Annual MSA maxima occur in summer, corresponding to sea-ice breakup and phytoplankton blooms within the polynyas.
2007 (23-25 ppb), and February and December 2008 $(22 \mathrm{ppb})$. For most years, there is also one or more smaller winter peaks in MSA concentration (2.5-10 ppb) that coincide with midwinter openings within the AS and PIB polynyas (Figure 5). The largest winter MSA peaks occur during May 2002 (4 ppb), August 2002 (5 ppb), September 2003 (10 ppb), July 2005 (4 ppb), and May/June 2007 (3 ppb, Figure 5). MSA concentrations associated with winter polynya events that occur during months of nonzero insolation south of latitude $70^{\circ} \mathrm{S}$ (April/August/September, 5-12 ppb) are higher than the winter MSA peaks that occur during months of zero insolation south of latitude $70^{\circ} \mathrm{S}$ (May/June/July, 3-4 ppb).

\section{3. $\mathrm{Cl}^{-}$and MSA Spatial Correlations With Sea-Ice Concentration}

[22] $\mathrm{Cl}^{-}$and MSA concentrations from the DIV2010 site (2002-2010) exhibit correlation patterns with SIC inside the AS and PIB polynya areas, as well as some regions outside the polynyas (Figures 6 and 7, hatch pattern indicates areas statistically significant at $p<0.1$, monthly threshold $|r|>0.169$ and seasonal threshold $|r|>0.622$, accounting for differing degrees of freedom). Focusing first within these masked polynya areas (as defined in section 2.3 above) we find that monthly- and seasonally-averaged MSA and $\mathrm{Cl}^{-}$concentrations show significant correlation with monthly and seasonal SIC for some areas within the polynyas (Table 1). $\mathrm{Cl}^{-}$concentrations show a moderate positive correlation with monthly SIC in the AS polynya $\left(r_{\max }=0.25\right)$, a strong positive correlation with winter SIC in the AS polynya $\left(r_{\max }=0.65\right)$, and no correlation with summer SIC at $p<0.1$ (Figure 6). MSA concentrations show a strong negative correlation with monthly SIC in both polynyas $\left(r_{\max }=-0.65\right)$ as expected from our definition of the polynya masks, a strong negative correlation with winter SIC in the AS polynya $\left(r_{\max }=-0.8\right)$, and a strong negative correlation with summer SIC in both polynyas $\left(r_{\max }=-0.8\right.$, Figure 7$)$ at $p<0.1$ (Table 1).

[23] Monthly and seasonal correlations between sea-ice outside of these polynya areas and ice-sheet chemistry are

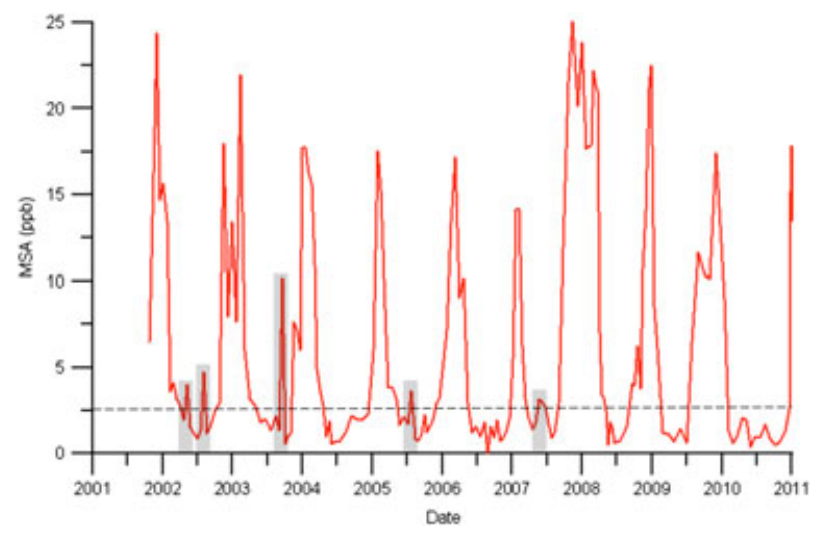

Figure 5. MSA in the DIV2010 core. Winter months (April-September) discussed are highlighted by the grey shading. The small but consistent winter peaks in MSA at the DIV2010 site correspond to winter polynya activity (MSA detection limit is $2.5 \mathrm{ppb}$, indicated by the dashed black line). $X$-axis years indicate the start (January) of a year. 

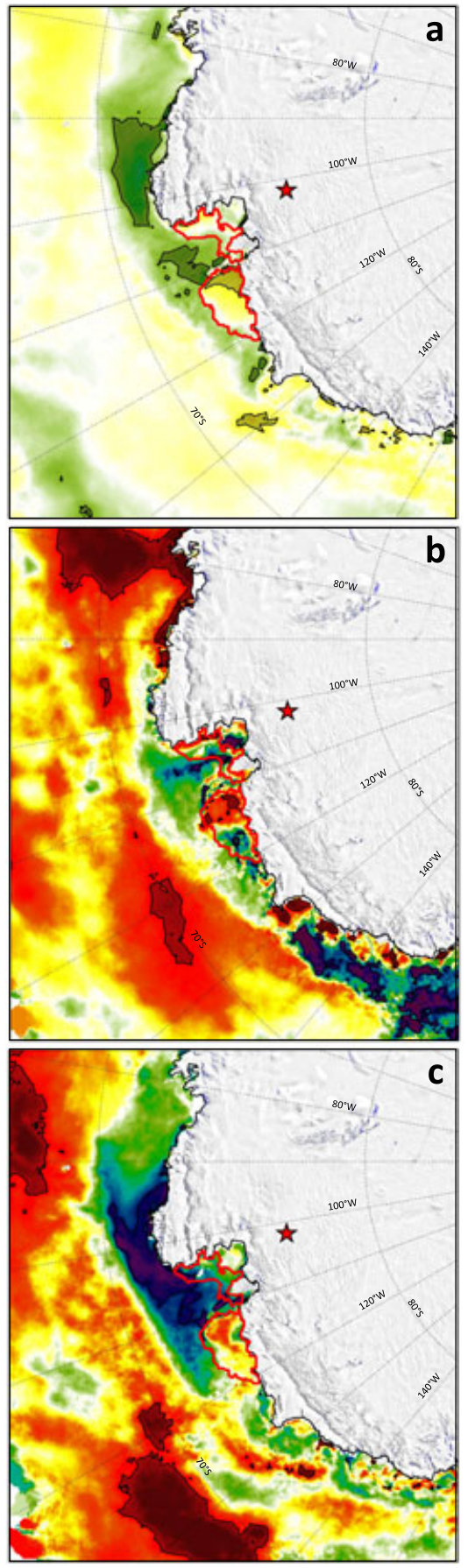

Correlation Coefficient (R)

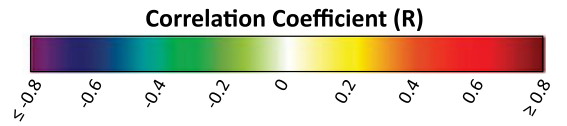

Figure 6. Spatial correlation map of (a) monthly, (b) winter (April to September), and (c) summer (October to March) $\mathrm{Cl}^{-}$ concentrations in the DIV2010 core with AMSR-E SIC around Antarctica. Figures show the AS and PIB masks outlined in red for reference. Hatch pattern indicates areas statistically significant at $p<0.1$ (monthly threshold $|r|>0.169$, seasonal threshold $|r|>0.622$, accounting for differing degrees of freedom). There are positive monthly and winter correlations between $\mathrm{Cl}^{-}$concentrations at the core site and sea ice within the AS and PIB polynyas, driven primarily by winter sea-ice formation.
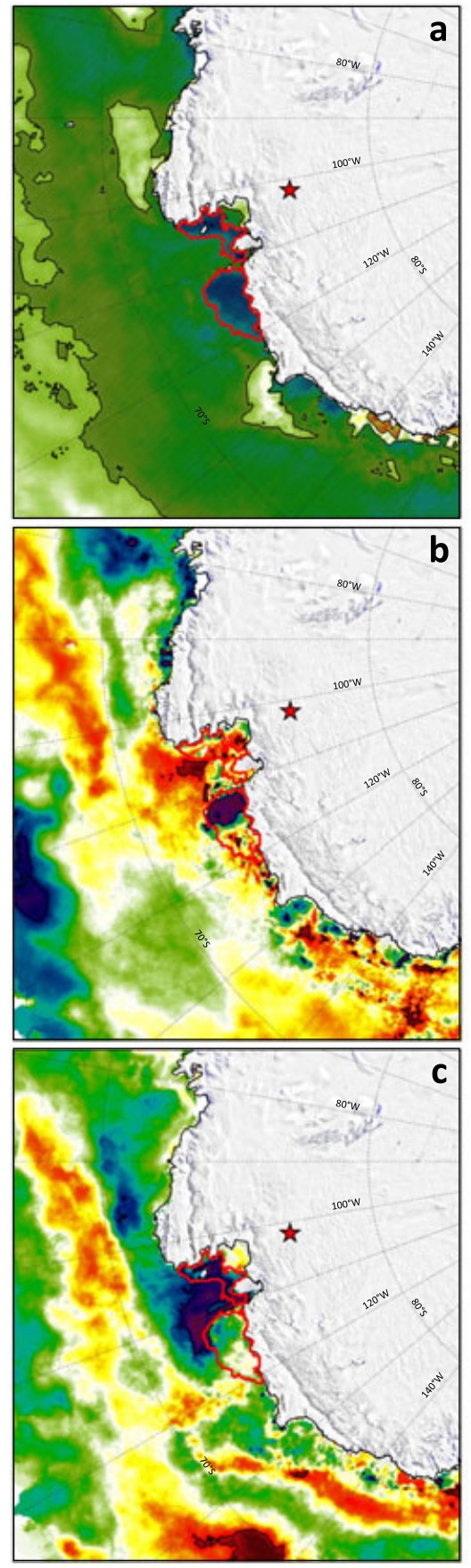

Correlation Coefficient (R)

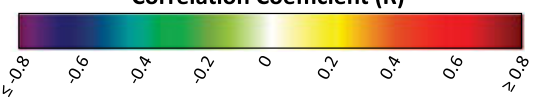

Figure 7. Spatial correlation map of (a) monthly, (b) winter (April to September), and (c) summer (October to March) MSA concentrations in the DIV2010 core with AMSR-E SIC around Antarctica. Figures show the AS and PIB masks outlined in red for reference. Hatch pattern indicates areas statistically significant at $p<0.1$ (monthly threshold $|r|>0.169$, seasonal threshold $|r|>0.622$, accounting for differing degrees of freedom). There are strong negative monthly and summer correlations between MSA concentrations at the core site and sea ice within the AS and PIB polynyas, driven primarily by annual integrated polynya open water area and associated phytoplankton blooms. 
Table 1. Correlations $(p<0.1)$ Between $\mathrm{MSA} \mathrm{Cl}^{-}$and Water Area/SIC Parameters Within the Polynyas, at $/$north of $70^{\circ} \mathrm{S}$, and Northeast of PIB (nc $=$ Not Statistically Significant at $p<0.1$, SIC $=$ Sea-ice Concentration, TWA $=$ Total Polynya Open Water Area, OW Days $=$ Annual Days With Less Than 50\% Sea-ice Cover, OW(max)= Maximum Annual Polynya Open Water Area, IWA=Annual Integrated Total Polynya Open Water Area, $\mathrm{MSA} / \mathrm{Cl}^{-}(\mathrm{sum})=$ Annual Integrated $\left.\mathrm{MSA} / \mathrm{Cl}^{-}, \mathrm{MSA} / \mathrm{Cl}^{-}(\max )=\operatorname{Maximum~Annual~} \mathrm{MSA} / \mathrm{Cl}^{-}\right) \cdot R$-values Reported Are the Maximum $r$-value Within the Geographic Region Described

\begin{tabular}{|c|c|c|c|}
\hline & Within Polynyas & AS at/north of $70^{\circ} \mathrm{S}$ & NE of PIB \\
\hline Monthly SIC and monthly MSA & -0.65 & -0.20 & -0.20 \\
\hline Winter SIC and winter MSA & $-0.80(\mathrm{AS})$ & -0.60 & nc \\
\hline Summer SIC and summer MSA & -0.80 & 0.80 & -0.80 \\
\hline Monthly SIC and monthly $\mathrm{Cl}^{-}$ & $0.25(\mathrm{AS})$ & nc & -0.30 \\
\hline Winter SIC and winter $\mathrm{Cl}-$ & 0.65 (AS) & 0.60 & nc \\
\hline Summer SIC and summer $\mathrm{Cl}^{-}$ & nc & 0.80 & -0.80 \\
\hline Monthly TWA and monthly MSA & 0.57 & & \\
\hline Summer TWA and summer MSA & 0.41 & & \\
\hline Winter TWA and winter $\mathrm{Cl}^{-}$ & -0.22 & & \\
\hline OW days and MSA(max) & 0.65 & & \\
\hline IWA and MSA(max) & 0.66 & & \\
\hline IWA and MSA(sum) & 0.54 & & \\
\hline $\mathrm{OW}(\max )$ and MSA(sum) & 0.50 & & \\
\hline $\mathrm{OW}(\max )$ and MSA(max) & 0.49 & & \\
\hline $\mathrm{OW}(\max )$ and $\mathrm{Cl}^{-}(\max )$ & 0.68 & & \\
\hline
\end{tabular}

generally weaker $(|r|<0.2)$, although with notable exceptions. Winter $\mathrm{Cl}^{-}$concentrations and winter SIC show strong positive correlation $(r=0.6)$ in two regions in the AS north of $70^{\circ} \mathrm{S}$ (Figure 6). $\mathrm{Cl}^{-}$and SIC in these two regions correlate in summer and winter, and are most strongly correlated and cover a larger area in the AS in summer. Summer $\mathrm{Cl}^{-}$ concentrations and summer SIC also show strong negative correlations with the coastal AS region northeast of the PIB polynya (between $\sim 70^{\circ} \mathrm{S}-72^{\circ} \mathrm{S}$ and $\sim 97^{\circ} \mathrm{W}-107^{\circ} \mathrm{W}$, $r=-0.8$, Figure 6). Monthly and summer MSA concentrations and monthly and summer SIC also show strong correlations ( $r=-0.3$ and -0.8 , respectively) northeast of PIB polynya, and north of $70^{\circ} \mathrm{S}$ between $\sim 130^{\circ} \mathrm{W}-140^{\circ} \mathrm{W}$ in summer $(r=0.8)$ in the AS (Figure 7, Table 1).

\section{4. $\mathrm{Cl}^{-}$and MSA Correlations With Interannual Polynya Open Water Area}

[24] We next investigate the temporal relationship between the masked polynyas and glaciochemical time series from 2002-2010 (Figure 2) to determine how well the DIV2010 ice-core chemical records capture the interannual variability in polynya open water (defined as $<15 \%$ SIC). We note that while it is assumed that sea-ice breakup leads MSA increase, we cannot say for all years whether one lags the other because we would need resolution of better than 7 days, which cannot be achieved using ice cores (global annual lifetimes of DMS and MSA are 1.8 and 6.7 days, respectively [e.g., Hezel et al., 2011]). For some years (2003, 2007-2009), however, MSA increase clearly does lead sea-ice breakup (Figure 2), suggesting the marine aerosols must also have a source outside of the polynya regions (discussed in section 4). All $r$-values reported are statistically significant $(p<0.1)$. There is a negative correlation between mean winter $\mathrm{Cl}^{-}$and mean winter total polynya open water area $(r=-0.22)$, suggesting that polynyas could be contributing to higher rates of sea-ice production in winter and higher $\mathrm{Cl}^{-}$concentrations. Mean summer $\mathrm{Cl}^{-}$and mean summer total polynya open water area are not significantly correlated. Monthly mean $\mathrm{Cl}^{-}$concentration and monthly mean total polynya water area are also not significantly correlated. A strong relationship was found between the maximum annual open water area within the polynyas and the maximum annual $\mathrm{Cl}^{-}$concentration $(r=0.68$, Table 1$)$. No significant correlations were found between annual $\mathrm{Cl}^{-}$ flux and any polynya variables (annual integrated open water area, maximum annual open water area, or annual number of days with $<50 \%$ sea-ice cover).

[25] Monthly mean MSA concentration and monthly mean total polynya water area are significantly positively correlated $(r=0.57)$ as are mean summer MSA concentration and mean summer total polynya water area $(r=0.41$, Figure 2). There is a strong relationship between the annual integrated open water area within the polynyas and the maximum annual MSA concentration $(r=0.66)$, and between the annual number of days with $<50 \%$ sea-ice cover and the maximum annual MSA concentration $(r=0.65)$. Strong relationships were also found between the annual integrated open water area within the polynyas and the annual integrated MSA concentration $(r=0.54)$, the maximum annual open water area within the polynyas and the annual integrated MSA concentration $(r=0.50)$, and the maximum annual open water area within the polynyas and the maximum annual MSA concentration $(r=0.49$, Figure 2$)$. No statistically significant correlations $(p<0.1)$ were found between annual MSA flux and any polynya variables (annual integrated open water area, maximum annual open water area, or annual number of days with $<50 \%$ sea-ice cover).

\section{Discussion}

\subsection{Sea-Salt Variability and Polynya Activity}

[26] Our results show that the strongest correlations between regional SIC and $\mathrm{Cl}^{-}$concentrations over the period 2002-2010 occur during winter within the AS polynya (positive correlation), year-round in the AS north of $70^{\circ} \mathrm{S}$ (positive correlation), and during summer in the AS northeast of the PIB polynya (between $\sim 70^{\circ} \mathrm{S}-72^{\circ} \mathrm{S}$ and $\sim 97^{\circ} \mathrm{W}-107^{\circ} \mathrm{W}$, negative correlation). This area of strong negative correlation northeast of the PIB polynya during summer generally retains thick multiyear sea ice, and 
summer openings therefore may generate sea-ice production instead of melt. These results indicate that $\mathrm{Cl}^{-}$may result from sea-ice production in both summer and winter (Figure 4), and open water sources (including wind-blown sea spray) northeast of the PIB polynya primarily in summer (Figure 6).

[27] In winter, the area of strong positive correlation lies along and offshore of the continental shelf break, whereas over the continental shelf (outside of the polynyas), correlations are negative. Offshore, high sea-ice production is likely associated with ice-edge advance, resulting in high SIC and explaining the positive correlations. In contrast, farther south over the continental shelf, sea ice is typically more consolidated pack ice. Thus new sea-ice production likely follows new openings (leads), which could explain the negative correlations between SIC and $\mathrm{Cl}^{-}$in this area.

[28] New winter sea-ice surfaces within the AS polynya may also contribute to the sea-salts in the DIV2010 core. Winter polynyas can produce substantial amounts of sea ice, as newly-formed ice is quickly removed by offshore winds, making way for additional sea-ice formation [Cavalieri, 1985; Wagenbach et al., 1998]. The presence of polynyas during winter has been suggested to be the largest source of marine aerosols in West Antarctica from both sea spray and frost flowers [Kaspari et al., 2005]. Blowing snow released from sea-ice surfaces has also been suggested to be a large source of marine aerosols [Yang et al., 2008]. This study, however, finds that the rapid, continual development of new sea ice within polynyas (and at the leading ice edge) is likely a significant source of sea-salt aerosols to the DIV2010 site during winter months. Furthermore, the timing of the highest sea-salt concentrations (i.e., winter) coincides with the season of greatest storminess and strongest winds along the Amundsen Coast [Kreutz et al., 2000]. This suggests that there is also a strong wind-driven influence on sea salts deposited at the DIV2010 site. Future investigations of regional wind-driven transport are needed to help differentiate between the different source regions.

[29] Our results are consistent with findings of others, who have also found that seasonal maxima in firn-core sea salts correlate well with winter maxima in SIC [e.g., Rankin et al., 2002; Wolff et al., 2003; Abram et al., 2011]. Some variations in seasonal and interannual variability of the $\mathrm{Cl}^{-}$ record at the DIV2010 site are also likely due to the impacts of varying winds and transport efficiency on sea-salt aerosol deposition. It has been previously suggested that storminess over the ocean and strength of inland transport, both of which are enhanced during winter, can explain the winter maxima in sea-salt records at many coastal sites [Petit et al., 1999]. Therefore, the consistent winter maxima in sea-salt concentrations at the DIV2010 site (Figure 4) are likely the result of both intense sea-ice formation in the region (in the open ocean and polynya areas, as discussed above), as well as increased winds during winter. We note here that the timing of the $\mathrm{Cl}^{-}$maxima post-2008, while still occurring during winter months as defined in this study, is less consistent than pre-2008 (Figure 2). As in other studies [e.g., Wolff et al., 2003], we find that the transport of sea salts resulting from new ice formation likely represents an important process in the transfer of ocean sea salts to the core site, particularly during the time of winter sea-ice maximum. The source and transport effects on sea-salt variability likely combine to strengthen the signal preserved in the sea-salt concentration of the DIV2010 core. Analysis of nearby ITASE cores showed that the ice-core sea-salt records are controlled in large part by wind strength, whether the aerosols are derived from frost flowers or open-ocean surfaces [Kaspari et al., 2005]. By examining the spatial distribution of marine aerosols across West Antarctica, the authors of this study also confirmed that the dominant source region for the Pine Island-Thwaites sector of WAIS is not the Ross Sea, but rather the Amundsen-Bellingshausen Sea. The quantitative effects of transport variability on the DIV2010 sea-salt record lie outside the scope of this paper (e.g., evaluation of reanalysis winds) but deserve future investigation.

\subsection{MSA Variability and Polynya/Post-polynya Activity}

[30] Our results show that the strongest negative correlations between regional SIC and MSA concentrations over the period 2002-2010 (monthly and summer) occur within the AS and PIB polynyas/post-polynyas (Figure 7). Our results also show that annual MSA maxima occur in summer when post-polynya open water is at a maximum, and annual MSA minima occur in winter when polynya open water is at a minimum (Figure 4). Monthly and summer MSA concentration and monthly and summer total polynya water area (the inverse of SIC, which is shown in Figure 7) are significantly positively correlated. These results suggest that seaice breakup within the post-polynyas in the austral summer, and size of the assumed associated annual phytoplankton bloom, is a primary source of MSA to the core site. This is similar in principle to the findings of Curran et al. [2003], who found that annual MSA concentrations were dependent on winter SIC (because summer SIC in their region of study was close to zero, and thus invariable from year to year). In this study, the MSA concentrations are dependent on the timing and variability of summer polynya activity, because there is little change in winter SIC (limited winter polynya activity) from year to year.

[31] In addition, the positive summer correlations noted previously lie along the continental shelf break. High SIC during summer months in this area may be associated with enhanced ice-edge blooms resulting from the retreating ice edge which can induce stratification and promote ice-edge productivity. The percent open water within the AS polynya is greater than the percent open water within the PIB polynya for all summers between 2002-2010, suggesting that the AS polynya may be a more significant source of DMS than the PIB polynya. This is consistent with the hypothesis that a larger sea-ice breakup and more open water in summer will often result in larger phytoplankton blooms and increased release of DMS, which others have shown [Pasteur et al., 1995; Isaksson et al., 2005; Abram et al., 2007; Rhodes et al., 2009; Abram et al., 2011; Arrigo et al., 2012]. This is also consistent with several studies that show that polynyas can produce more significant fluxes of DMS into the overlying atmosphere than adjacent waters in the sea-ice zone [Zemmelink et al., 2005, 2008; Tison et al., 2010; Asher et al., 2011; Brabant et al., 2011].

[32] Our results also show that there are significant correlations between annual integrated polynya open water area 
and maximum annual MSA concentration, as well as annual number of days with $<50 \%$ sea-ice cover (calculated from the open water time series) and maximum annual MSA concentration. Annual integrated polynya open water area (not the maximum polynya size attained), then, has a more significant effect on maximum annual MSA concentrations at the core site. These results suggest that the length of time the polynyas are at least partially open during spring and summer strongly affects the size of the summer phytoplankton bloom (shown by others, e.g., Arrigo et al., 2012), amount of DMS produced in the polynyas/post-polynyas, and therefore the amount of MSA precipitated at the core site. High DMS concentrations and turnover rates in ice-free Antarctic polynya waters, particularly under late summer conditions of high solar irradiance and mixed layer stratification, have been documented in nearby polynyas [e.g., Asher et al., 2011]. With sufficient sunlight and adequate upwelling, a polynya event that is small in area but of long duration may result in higher DMS production (and ultimately higher MSA concentrations) than a large but short-duration polynya event.

\subsection{Winter MSA Variability}

[33] Our results show wintertime increases in MSA coincident with openings within the AS polynya. As this is the first time wintertime peaks in MSA have been reported, we spend some time here to discuss proposed processes associated with these peaks. This winter polynya activity occurs during times of both nonzero and zero insolation in the polynya regions. Winter polynya events that occur during times of nonzero insolation result in higher MSA concentrations than winter polynya events that occur during times of zero insolation, however neither are as high as summer MSA concentrations. We propose different mechanisms that might explain these winter increases in MSA. During times of low but nonzero insolation, the wintertime MSA signal may originate from new, albeit reduced, primary production within the polynyas similar to summer. During times of zero insolation, the MSA signal may originate from release of previously stored DMS in sea ice within the polynyas, or from source regions farther offshore (north of $65^{\circ} \mathrm{S}$ ) that do receive radiation year-round. In either case, the production of oxidants that convert DMS to MSA in the atmosphere is not a limiting factor, as oxidation is initiated by $\mathrm{OH}$ in sunny regions, and by $\mathrm{NO}_{3}$ in dark regions [Ravishankara et al., 1997] (although we note that the relative conversion of DMS to MSA and sulfate aerosols may be seasonally variable). We discuss the proposed mechanisms below.

[34] For years when winter polynya opening occurs when insolation is nonzero (before May or after July), the limited light may be sufficient to support biological productivity within the polynyas when other contributing factors such as adequate upwelling are present. This may be the case in August 2002, September 2003, and August 2005; times when insolation is weak but potentially sufficient to support new productivity in polynya surface waters with sea-ice breakup.

[35] For years when winter polynya opening occurs when insolation is zero (May 2002 and May 2007), an alternative explanation is required to explain the winter MSA peaks. It is improbable that DMS or DMSP from a previous summer would be present in deep water [Matrai et al., 1995; Rellinger et al., 2009]. Instead, winter MSA and winter SIC spatial correlation results indicate that part of the winter MSA source may come from farther offshore in the AS during winter (between $\sim 64^{\circ} \mathrm{S}-67^{\circ} \mathrm{S}$ and $\sim 107^{\circ} \mathrm{W}-115^{\circ} \mathrm{W}$, Figure $7 \mathrm{~b}$ ). This region of moderate negative winter correlation receives sunlight year-round. While insolation from May to July in this region of the AS (north of $65^{\circ} \mathrm{S}$ ) is severely limited, the small amount of radiation may be sufficient both for supporting productivity in open water and for oxidizing DMS to MSA in the atmosphere by several oxidation pathways. DMS emissions have been shown to peak at $66^{\circ} \mathrm{S}$ [Hezel et al., 2011], further supporting the feasibility of a winter MSA source component from the AS north of $65^{\circ} \mathrm{S}$.

[36] The wintertime peaks may additionally be attributed to release of previously stored DMS in sea ice that is in turn released upon wind-driven sea-ice fragmentation during winter polynya openings. This may be the case in May 2002 and May/June 2007. The MSA record, in such instances, may be indicative of a polynya opening, which can be seen both in reconstructions of polynya SIC as well as in AWS temperature data and the $\delta^{18} \mathrm{O}$ record (Figure 2) showing midwinter warming during such polynya events. These polynya openings appear to allow for the transfer of stored DMS in sea ice to the atmosphere. It is possible that release of previously stored DMS in sea ice enhances both the summer and winter MSA signal. Several studies have shown evidence of "old" DMSP in winter sea ice from the previous spring/summer bloom, which can be released upon sea-ice breakup and surface flooding [Trevena et al., 2003; Elliott et al., 2009; Nomura et al., 2011; Tison et al., 2010]. It has been shown that the snow layer covering sea ice is important because it is the interface through which DMS needs to be transported to be emitted from the ice to the overlying atmosphere [Zemmelink et al., 2008]. In Antarctic sea ice, flooding of this sea-ice snow cover allows infiltration of the surface layers [Arrigo et al., 1997], which can permit release of DMSP within the sea ice. When sea ice becomes fragmented and is forced offshore by wind during polynya events, the breakup itself can be mechanism enough for release of DMS contained in the sea ice. While the oxidation pathways of DMS to MSA are greatly inhibited during times of zero solar radiation, DMS oxidation does occur year-round. During polar darkness, oxidation of DMS to MSA via BrO pathways increases in importance, and improves the potential for retaining local signals of DMS emissions in MSA deposition at coastal sites [Breider et al., 2010].

\section{Conclusions}

[37] This work investigates the use of MSA and $\mathrm{Cl}^{-}$ concentrations in a new coastal firn core from the divide between Thwaites and Pine Island glaciers as proxies for sea-ice behavior and polynya variability in the AS and PIB. We compare MSA and $\mathrm{Cl}^{-}$concentrations in the core with satellite-derived reconstructions of SIC (2002-2010) around coastal West Antarctica. The high annual accumulation rate at the core site $\left(10\right.$ year mean $\left.\sim 39 \mathrm{~g} \cdot \mathrm{cm}^{-2} \cdot \mathrm{yr}^{-1}\right)$ results in a monthly- to seasonally-resolved record of MSA and $\mathrm{Cl}^{-}$, allowing us to investigate how sea-ice and polynya variability is recorded in the firn-core record. Our key 
findings are that: (1) firn-core records and regional SIC correlate strongly within AS and PIB polynyas, (2) monthly and summer MSA concentrations are significantly negatively correlated with monthly and summer polynya SIC ( $r=-$ 0.65 and -0.8 , respectively; $p<0.1)$, (3) monthly and winter $\mathrm{Cl}^{-}$concentrations are positively correlated with monthly and winter polynya SIC $(r=0.25$ and 0.65 , respectively; $p<0.1$ ), summer $\mathrm{Cl}^{-}$concentrations are negatively correlated with SIC in the coastal AS northeast of the PIB polynya (between $\sim 70^{\circ} \mathrm{S}-72^{\circ} \mathrm{S}$ and $\sim 97^{\circ} \mathrm{W}-107^{\circ} \mathrm{W}, r=-0.8, p<0.1$ ), and winter and summer $\mathrm{Cl}^{-}$concentrations and winter and summer SIC show strong positive correlation $(r=0.6)$ in the AS north of $70^{\circ} \mathrm{S}$, and (4) interannual monthly and summer MSA concentration and interannual monthly and summer total polynya water area are significantly correlated $(r=0.57$ and 0.41 , respectively; $p<0.1$. While significant correlations exist between MSA $/ \mathrm{Cl}^{-}$and SIC in some regions in the AS outside of the polynya areas, our results suggest that MSA peaks are in large part a result of new biological productivity in summer following polynya openings, with smaller winter MSA peaks reflecting stored DMS/DMSP in sea ice released during polynya sea-ice breakup, or transport of MSA from farther offshore in the AS. Our results also suggest that sea salts, predominantly deposited in the winter, are originating in large part from winter sea-ice formation within the AS polynya. In summer, sea salts appear to originate primarily from open water sources in the coastal AS northeast of PIB. The summer open water source along $70^{\circ} \mathrm{S}$ (Figure 6) likely reflects ice-edge advance which occurs predominantly in March and is marked by rapid sea-ice production.

[38] Our results are in agreement with many proxy development studies at other locations in Antarctica that have shown the primary source of MSA to coastal sites to be new summertime biological productivity following sea-ice breakup. Our results are also in agreement with previous work showing the presence of polynyas during winter to be one of the sources of marine aerosols in West Antarctica from both sea spray and frost flowers, owing to the continual development of new sea ice within polynyas. In addition, our results suggest that initiation of new sea-ice production in leads on the continental shelf, as well as new sea-ice production associated with ice-edge advance offshore of the continental shelf, may be other significant sources of marine aerosols to the DIV2010 core site.

[39] The location and temporal resolution of the DIV2010 core allow us to investigate how monthly to seasonal changes in AS SIC as well as AS and PIB polynya SIC are recorded in the adjacent ice sheet. Owing to the high resolution of the DIV2010 core, and its proximity to PIB, we are able to show that interannual MSA and sea-salt variability are driven in part by interannual AS and PIB polynya variability. Our results show that winter mean $\mathrm{Cl}^{-}$concentrations from this region best capture winter polynya SIC and SIC in two regions in the AS north of $70^{\circ} \mathrm{S}(r=0.65$, Figure 6), while maximum annual $\mathrm{Cl}^{-}$concentrations best capture the maximum annual open water in the polynyas $(r=0.68)$. Our results also suggest that maximum annual MSA concentrations at the core site best capture annual integrated AS and PIB post-polynya open water area variability $(r=0.65)$, although other influences (e.g., productivity outside the polynyas and atmospheric transport variability) undoubtedly also contribute to the MSA variability at DIV2010. This holds promise that the combined use of sea-salt and MSA records in future studies may allow us to reconstruct seasonal changes in regional sea-ice behavior and polynya variability beyond the satellite era, bridging a key gap in our understanding of past climate and sea-surface conditions. Analysis of ice-core records from other sites across the Amundsen Sea Embayment will additionally allow us to assess the reliability of similar proxy records across the ice sheet.

[40] Ice-core marine aerosol records are influenced by both source and transport variability. This study, which focuses on the spatial relationships between satellite-derived SIC (including polynya activity) and ice-sheet chemistry across the AS (including PIB), furthers our understanding of the source variability. Transport variability (including how these marine aerosol records relate to large-scale atmospheric circulation as well as tropical teleconnections) requires proper treatment of its own, and will be the focus of future work.

[41] Acknowledgments. Thanks to Luke Trusel, Lou Albershardt, and RPSC support staff for assistance in the field. Thanks to Emily Medeiros and Lauren Thompson for assistance with MSA and $\mathrm{Cl}^{-}$measurements, and $\Delta^{*}$ IsoLab at the University of Washington for assistance with the isotope measurements. Naomi Levine and Ted Maksym provided helpful discussions during the preparation of this manuscript. The authors thank the three anonymous reviewers, whose comments greatly helped improve the original manuscript. This research was supported by an award from the Department of Energy Office of Science Graduate Fellowship Program (DOE SCGF) to ASC, a James E. and Barbara V. Moltz Research Fellowship to SBD, and by grants from NSF-OPP (\#ANT-0632031 \& \#ANT-0631973); NSF-MRI (\#EAR-1126217); NASA Cryosphere Program (\#NNX10AP09G); and a WHOI Andrew W. Mellon Foundation Award for Innovative Research.

\section{References}

Abram, N. J., R. Mulvaney, and C. Arrowsmith (2011), Environmental signals in a highly resolved ice core from James Ross Island, Antarctica, J. Geophys. Res., 116(D20), D20116, doi:10.1029/2011JD016147.

Abram, N. J., R. Mulvaney, E. W. Wolff, and M. Mudelsee (2007), Ice core records as sea ice proxies: An evaluation from the Weddell Sea region of Antarctica, J. Geophys. Res., 112(D15), D15101, doi:10.1029/ 2006JD008139.

Abram, N. J., E. R. Thomas, J. R. McConnell, R. Mulvaney, T. J. Bracegirdle, L. C. Sime, and A. J. Aristarain (2010), Ice core evidence for a 20th century decline of sea ice in the Bellingshausen Sea, Antarctica, J. Geophys. Res., 115(D23), D23101, doi:10.1029/2010JD014644.

Arrigo, K. R., and G. L. van Dijken (2003), Phytoplankton dynamics within 37 Antarctic coastal polynya systems, J. Geophys. Res., 108(C8), 3271. Arrigo, K. R., D. L. Worthen, M. P. Lizotte, P. Dixon, and G. Dieckmann (1997), Primary Production in Antarctic Sea Ice, Science, 276(5311), 394-397.

Arrigo, K. R., G. R. DiTullio, R. B. Dunbar, D. H. Robinson, M. VanWoert, D. L. Worthen, and M. P. Lizotte (2000), Phytoplankton taxonomic variability in nutrient utilization and primary production in the Ross Sea, J. Geophys. Res., 105(C4), 8827-8846.

Arrigo, K. R., K. E. Lowry, and G. L. van Dijken (2012), Annual changes in sea ice and phytoplankton in polynyas of the Amundsen Sea, Antarctica, Deep Sea Research Part II: Topical Studies in Oceanography, 71-76(0), $5-15$.

Asher, E. C., J. W. H. Dacey, M. M. Mills, K. R. Arrigo, and P. D. Tortell (2011), High concentrations and turnover rates of DMS, DMSP and DMSO in Antarctic sea ice, Geophys. Res. Lett., 38(23), L23609.

Bindoff, N. L., G. D. Williams, and I. Allison (2001), Sea-ice growth and water-mass modification in the Mertz Glacier polynya, East Antarctica, during winter, Annals of Glaciology, 33(1), 399-406.

Brabant, F., S. El Amri, and J. L. Tison (2011), A robust approach for the determination of dimethylsulfoxide in sea ice, Limnology and Oceanography: Methods, 9, 261-274.

Breider, T. J., M. P. Chipperfield, N. A. D. Richards, K. S. Carslaw, G. W. Mann, and D. V. Spracklen (2010), Impact of BrO on 


\section{CRISCITIELLO ET AL.: ICE SHEET RECORD OF SEA-ICE VARIABILITY}

dimethylsulfide in the remote marine boundary layer, Geophys. Res. Lett., 37(2), L02807.

Cavalieri, D. J. (1985), A passive microwave study of polynyas along the Antarctic Wilkes Land Coast, Oceanology of the Antarctic Continental Shelf, Antarct.Res.Ser., 43, 227-252.

Comiso, J. C., and F. Nishio (2008), Trends in the sea ice cover using enhanced and compatible AMSR-E, SSM/I, and SMMR data, J. Geophys Res., 113(C2), C02S07.

Curran, M. A. J., and G. B. Jones (2000), Dimethyl sulfide in the Southern Ocean: Seasonality and flux, J. Geophys. Res., 105(D16), 20451-20459.

Curran, M. A. J., and A. S. Palmer (2001), Suppressed ion chromatography methods for the routine determination of ultra low level anions and cations in ice cores, Journal of Chromatography A, 919(1), 107-113.

Curran, M. A. J., T. D. van Ommen, V. I. Morgan, K. L. Phillips, and A. S. Palmer (2003), Ice core evidence for Antarctic sea ice decline since the 1950s, Science, 302(5648), 1203-1206.

Dacey, J. W. H., and S. G. Wakeham (1986), Oceanic dimethylsulfide: Production during zooplankton grazing on phytoplankton, Science, 233 (4770), 1314-1316.

Elliott, D., K. Tang, and A. Shields (2009), Mesozooplankton beneath the summer sea ice in McMurdo Sound, Antarctica: abundance, species composition, and DMSP content, Polar Biology, 32(1), 113-122.

Fichefet, T., and H. Goosse (1999), A numerical investigation of the spring Ross Sea polynya, Geophys. Res. Lett., 26(8), 1015-1018.

Fischer, H., et al. (2007), Reconstruction of millennial changes in dust emission, transport and regional sea ice coverage using the deep EPICA ice cores from the Atlantic and Indian Ocean sector of Antarctica, Earth and Planetary Science Letters, 260(1-2), 340-354.

Gibson, J. A. E., R. C. Garrick, H. R. Burton, and A. R. McTaggart (1990), Dimethylsulfide and the alga Phaeocystis pouchetii in Antarctic coastal waters, Marine Biology, 104(2), 339-346.

Grebmeier, J. M., and L. W. Cooper (1995), Influence of the St. Lawrence Island Polynya upon the Bering Sea benthos, J. Geophys. Res., 100 (C3), 4439-4460.

Hezel, P. J., B. Alexander, C. M. Bitz, E. J. Steig, C. D. Holmes, X. Yang, and J. Sciare (2011), Modeled methanesulfonic acid (MSA) deposition in Antarctica and its relationship to sea ice, J. Geophys. Res., 116(D23), D23214.

Isaksson, E., T. Kekonen, J. Moore, and R. Mulvaney (2005), The methanesulfonic acid (MSA) record in a Svalbard ice core, Annals of Glaciology, 42(1), 345-351.

Jacobs, S., A. Jenkins, C. F. Giulivi, and P. Dutrieux (2011), Stronger ocean circulation and increased melting under Pine Island Glacier ice shelf, Nature Geosci, 4(8), 519-523.

Jenkins, A., P. Dutrieux, S. S. Jacobs, S. D. McPhail, J. R. Perrett, A. T. Webb, and D. White (2010), Observations beneath Pine Island Glacier in West Antarctica and implications for its retreat, Nature Geosciences, 3(7), 468-472.

Joughin, I., E. Rignot, C. E. Rosanova, B. K. Lucchitta, and J. Bohlander (2003), Timing of recent accelerations of Pine Island Glacier, Antarctica, Geophys. Res. Lett., 30(13), 1706.

Jourdain, B., and M. Legrand (2001), Seasonal variations of atmospheric dimethylsulfide, dimethylsulfoxide, sulfur dioxide, methanesulfonate, and non-sea-salt sulfate aerosols at Dumont d'Urville (coastal Antarctica) (December 1998 to July 1999), J. Geophys. Res., 106(D13), 14391-14408.

Kaleschke, L., et al. (2004), Frost flowers on sea ice as a source of sea salt and their influence on tropospheric halogen chemistry, Geophys. Res. Lett., 31(16), L16114.

Kaspari, S., D. A. Dixon, S. B. Sneed, and M. J. Handley (2005), Sources and transport pathways of marine aerosol species into West Antarctica, Annals of Glaciology, 41(1), 1-9.

Kinnard, C., C. M. Zdanowicz, D. A. Fisher, and C. P. Wake (2006), Calibration of an ice-core glaciochemical (sea-salt) record with sea-ice variability in the Canadian Arctic, Annals of Glaciology, 44, 383-390.

Kreutz, K. J., P. A. Mayewski, I. I. Pittalwala, L. D. Meeker, M. S. Twickler, and S. I. Whitlow (2000), Sea level pressure variability in the Amundsen Sea region inferred from a West Antarctic glaciochemical record, J. Geophys. Res., 105(D3), 4047-4059.

Legrand, M., C. Hammer, M. De Angelis, J. Savarino, R. Delmas, H. Clausen, and S. J. Johnsen (1997), Sulfur-containing species (methanesulfonate and SO4) over the last climatic cycle in the Greenland Ice Core Project (central Greenland) ice core, J. Geophys. Res., 102(C12), 26663-26679.

Markus, T., and D. J. Cavalieri (2000), An enhancement of the NASA Team sea ice algorithm, IEEE Transactions on Geoscience and Remote Sensing, 38(3), 1387-1398.

Massom, R. A., P. T. Harris, K. J. Michael, and M. J. Potter (1998), The distribution and formative processes of latent-heat polynyas in East
Antarctica, in Annals of Glaciology, Vol 27, 1998, edited by W. F. Budd, pp. 420-426, Int Glaciological Soc, Cambridge.

Matrai, P. A., M. Vernet, R. Hood, A. Jennings, E. Brody, and S. Saemundsdóttir (1995), Light-dependence of carbon and sulfur production by polar clones of the genus Phaeocystis, Marine Biology, 124(1), 157-167.

Maykut, G. A. (1982), Large-scale heat exchange and ice production in the central Arctic, J. Geophys. Res., 87(C10), 7971-7984.

Morganti, A., S. Becagli, E. Castellano, M. Severi, R. Traversi, and R. Udisti (2007), An improved flow analysis-ion chromatography method for determination of cationic and anionic species at trace levels in Antarctic ice cores, Analytica Chimica Acta, 603(2), 190-198.

Mulvaney, R., E. C. Pasteur, D. A. Peel, E. S. Saltzman, and P.-Y. Whung (1992), The ratio of MSA to non-sea-salt sulphate in Antarctic Peninsula ice cores, Tellus B, 44(4), 295-303.

Mundy, C. J., and D. G. Barber (2001), On the relationship between spatial patterns of sea-ice type and the mechanisms which create and maintain the North Water (NOW) polynya, Atmosphere-Ocean, 39(3), 327-341.

Nicolas, J. P., and D. H. Bromwich (2011), Climate of West Antarctica and influence of marine air intrusions, Journal of Climate, 24(1), 49-67.

Nomura, D., N. Kasamatsu, K. Tateyama, S. Kudoh, and M. Fukuchi (2011), DMSP and DMS in coastal fast ice and under-ice water of Lützow-Holm Bay, eastern Antarctica, Continental Shelf Research, 31 (13), 1377-1383.

Pasteur, E. C., R. Mulvaney, D. A. Peel, E. S. Saltzman, and P.-Y. Whung (1995), A 340 year record of biogenic sulphur from the Weddell Sea area, Antarctica, Annals of Glaciology, 21, 169-174.

Petit, J. R., et al. (1999), Climate and atmospheric history of the past 420,000 years from the Vostok ice core, Antarctica, Nature, 399.

Rankin, A. M., E. W. Wolff, and S. Martin (2002), Frost flowers: Implications for tropospheric chemistry and ice core interpretation, $J$. Geophys. Res., 107(D23), 4683.

Ravishankara, A. R., Y. Rudich, R. Talukdar, and S. B. Barone (1997), Oxidation of atmospheric reduced sulphur compounds: Perspective from laboratory studies, Philosophical Transactions of the Royal Society of London. Series B: Biological Sciences, 352(1350), 171-182.

Rellinger, A. N., R. P. Kiene, D. A. del Valle, D. J. Kieber, D. Slezak, H. Harada, J. Bisgrove, and J. Brinkley (2009), Occurrence and turnover of DMSP and DMS in deep waters of the Ross Sea, Antarctica, Deep Sea Research Part I: Oceanographic Research Papers, 56(5), 686-702.

Rhodes, R. H., N. A. N. Bertler, J. A. Baker, S. B. Sneed, H. Oerter, and K. R. Arrigo (2009), Sea ice variability and primary productivity in the Ross Sea, Antarctica, from methylsulphonate snow record, Geophys. Res. Lett., 36(10), L10704.

Rignot, E., J. L. Bamber, M. R. van den Broeke, C. Davis, Y. Li, W. J. van de Berg, and E. van Meijgaard (2008), Recent Antarctic ice mass loss from radar interferometry and regional climate modelling, Nature Geosciences, 1(2), 106-110.

Roscoe, H. K., B. Brooks, A. V. Jackson, M. H. Smith, S. J. Walker, R. W. Obbard, and E. W. Wolff (2011), Frost flowers in the laboratory: Growth, characteristics, aerosol, and the underlying sea ice, J. Geophys. Res., 116(D12), D12301.

Röthlisberger, R., X. Crosta, N. J. Abram, L. Armand, and E. W. Wolff (2010), Potential and limitations of marine and ice core sea ice proxies: an example from the Indian Ocean sector, Quaternary Science Reviews, 29(1-2), 296-302.

Saigne, C., and M. Legrand (1987), Measurements of methanesulphonic acid in Antarctic ice, Nature, 330(6145), 240-242.

Schneider, D. P., C. Deser, and Y. Okumura (2011), An assessment and interpretation of the observed warming of West Antarctica in the austral spring, Climate Dynamics, 38(1-2), 323-347.

Smith, S. D., R. D. Muench, and C. H. Pease (1990), Polynyas and leads: An overview of physical processes and environment, J. Geophys. Res., 95(C6), 9461-9479.

Sneed, S. B., P. A. Mayewski, and D. A. Dixon (2011), An emerging technique: multi-ice-core multi-parameter correlations with Antarctic sea-ice extent, Annals of Glaciology, 52(57), 347-354.

Spreen, G., L. Kaleschke, and G. Heygster (2008), Sea ice remote sensing using AMSR-E 89-GHz channels, J. Geophys. Res., 113(C2), C02S03.

Steig, E. J., Q. Ding, D. S. Battisti, and A. Jenkins (2012), Tropical forcing of circumpolar deep water inflow and outlet glacier thinning in the Amundsen Sea Embayment, West Antarctica, Annals of Glaciology, 53(60), 19-28.

Steig, E. J., D. P. Schneider, S. D. Rutherford, M. E. Mann, J. C. Comiso, and D. T. Shindell (2009), Warming of the Antarctic ice-sheet surface since the 1957 International Geophysical Year, Nature, 457(7228), 459-462.

Tison, J. L., F. Brabant, I. Dumont, and J. Stefels (2010), High-resolution dimethyl sulfide and dimethylsulfoniopropionate time series profiles in 


\section{CRISCITIELLO ET AL.: ICE SHEET RECORD OF SEA-ICE VARIABILITY}

decaying summer first-year sea ice at Ice Station Polarstern, western Weddell Sea, Antarctica, J. Geophys. Res., 115(G4), G04044.

Toole, D. A., and D. A. Siegel (2004), Light-driven cycling of dimethylsulfide (DMS) in the Sargasso Sea: Closing the loop, Geophys. Res. Lett., 31(9), L09308.

Trevena, A. J., G. B. Jones, S. W. Wright, and R. L. van den Enden (2003), Profiles of dimethylsulphoniopropionate (DMSP), algal pigments, nutrients, and salinity in the fast ice of Prydz Bay, Antarctica, J. Geophys. Res., 108(C5), 3145.

Turner, J., J. C. Comiso, G. J. Marshall, T. A. Lachlan-Cope, T. Bracegirdle, T. Maksym, M. P. Meredith, Z. Wang, and A. Orr (2009), Non-annular atmospheric circulation change induced by stratospheric ozone depletion and its role in the recent increase of Antarctic sea ice extent, Geophys. Res. Lett., 36(8), L08502.

Wagenbach, D., F. Ducroz, R. Mulvaney, L. Keck, A. Minikin, M. Legrand, J. S. Hall, and E. W. Wolff (1998), Sea-salt aerosol in coastal Antarctic regions, J. Geophys. Res., 103(D9), 10961-10974.

Welch, K. A., P. A. Mayewski, and S. I. Whitlow (1993), Methanesulfonic acid in coastal Antarctic snow related to sea-ice extent, Geophys. Res. Lett., 20(6), 443-446.
Weller, R., F. Traufetter, H. Fischer, H. Oerter, C. Piel, and H. Miller (2004), Postdepositional losses of methane sulfonate, nitrate, and chloride at the European Project for Ice Coring in Antarctica deep-drilling site in Dronning Maud Land, Antarctica, J. Geophys. Res., 109(D7), D07301.

Wolff, E. W., A. M. Rankin, and R. Röthlisberger (2003), An ice core indicator of Antarctic sea ice production?, Geophys. Res. Lett., 30(22), 2158.

Wolff, E. W., et al. (2006), Southern Ocean sea-ice extent, productivity and iron flux over the past eight glacial cycles, Nature, 440(7083), 491-496.

Yang, X., J. A. Pyle, and R. A. Cox (2008), Sea salt aerosol production and bromine release: Role of snow on sea ice, Geophys. Res. Lett., 35(16), L16815.

Zemmelink, H. J., L. Houghton, J. W. H. Dacey, A. P. Worby, and P. S. Liss (2005), Emission of dimethylsulfide from Weddell Sea leads, Geophys. Res. Lett., 32(23), L23610.

Zemmelink, H. J., J. W. H. Dacey, L. Houghton, E. J. Hintsa, and P. S. Liss (2008), Dimethylsulfide emissions over the multi-year ice of the western Weddell Sea, Geophys. Res. Lett., 35(6), L06603.

Zwally, H. J., J. C. Comiso, C. L. Parkinson, D. J. Cavalieri, and P. Gloersen (2002), Variability of Antarctic sea ice $1979-1998$, J. Geophys. Res., 107(C5), 3041. 